\title{
Comparative study of hypercoagulability change in steady state and during vaso-occlusive crisis among Sudanese patients living with sickle cell disease
}

\author{
Elmigdad Abdelgadir Mohamed ${ }^{1}$, Mamoud Mohamed Elgari ${ }^{2}$, Asaad Mohammed Babker ${ }^{3}$, Hisham Ali Waggiallah ${ }^{4}$
}

1. Alghad International Colleges for Applied Medical Sciences, Educational and Academic Affairs.

2. Taibah university, college of Applied Medical science, Medical Laboratory Science.

3. Gulf Medical University, of Medical Laboratories Science.

4. Prince Sattam Bin Abdulaziz University College of Applied Medical Sciences, Medical Laboratory Sciences.

\begin{abstract}
:
Background: Sickle cell disease (SCD) is an inherited blood disorder that affects red blood cells. (SCD) is characterized by recurrent vaso-occlusive crisis (VOC).

Material and methods: This was a descriptive cross sectional study conducted through the period from July 2015 to July 2017 in which a total of seventy two blood specimens were collected in 'EDTA' and citrated vacutainers from Sudanese patients with SCD attending "Fath Elrhman Albasheer" Centre. Both sexes' with different ages were included. Among these samples 49 $(68.1 \%)$ were in steady state while the remained $23(31.9 \%)$ were in VOC. All samples were tested for coagulation profile

Result: There was increase in fibrinogen and D-dimer levels in most patients $67 \%$ and $71 \%$, respectively. Significant increase in D-dimers was observed in patients with (VOC) compared with steady state (P. value $=0.006$ ). Protein S was significantly increased in males in comparison with females $\mathrm{P}$. value $=0.017$. The results of prothrombin time $(\mathrm{PT})$, international normalized ratio (INR) and thrombin time (TT) were within normal range.

Conclusion: Significant increase in levels of D-dimer during VOC indicating abnormal coagulation and fibrinolysis activation. Reduced levels of natural anticoagulants proteins $\mathrm{C}$ and $\mathrm{S}$ can be consider as predictive markers indicate hepatic dysfunction in patients with SCD.
\end{abstract}

Keyword: SCD, VOC, hypercoagulability, Sudanese patients.

DOI: https://dx.doi.org/10.4314/ahs.v20i1.45

Cite as: Mohamed EA, Elgari MM, Babker AM, Waggiallah HA. Comparative study of hypercoagulability change in steady state and during vaso-occlusive crisis among Sudanese patients living with sickle cell disease. Afri Health Sci. 2020;20(1):392-6. https://dx.doi.org/10.4314/abs. $v 20 i 1.45$

\section{Introduction}

Sickle cell disease (SCD) is a painful, lifelong hemoglobinopathy withsubstantial morbidities and premature mortality. It is inherited as apoint mutation in the hemoglobin $(\mathrm{Hb})$ beta-globin gene where glu-tamic acid at position 6 is substituted by valine. This mutation providesresistance to malaria, but, in the homozygous form, results in SCD, which is characterized by anemia and painful vaso-occlusive crises (VOCs). The change in molecular structure allows $\mathrm{Hb}$ in the deoxygen-ated state to form polymers that promote $\mathrm{Hb}$ autoxidation, redblood cell
Corresponding author:
Hisham Ali Waggiallah,
Prince Sattam Bin Abdulaziz University,
College of Applied Medical Sciences, Medical
Laboratory Sciences.
Email: hishamwagg30@hotmail.com

(RBC) membrane damage, decreased RBC deformability, intravascular and extravascular hemolysis, inflammation, vaso-occlusion, and ultimately organ injury ${ }^{1}$

The complications of this disease are numerous and affected every organ and tissue in the body. Thrombotic manifestations and organ damage develop since early infancy because the coagulation system in children with SCD has been poorly explored. Increased thrombin generation and fibrin dissolution are present in children with $\mathrm{SCD}^{2}$. The severity in the clinical course of sickle cell disease is influenced by variety of intracellular and extracellular factors and characterized by variable period of steady state that is periodically punctuated by vaso-occlusive crisis $^{3}$. Majority of the sickle cell patients are relatively stable much of the time and are said to be in a steady state because they achieve a steady state level of fitness. The steady state may be periodically interrupted by hemolytic crises which may be acute and fatal ${ }^{4}$.

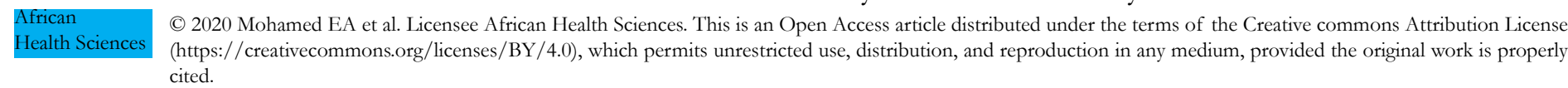


The major clinical features of SCD are acute vaso-occlusive manifestations and chronic haemolytic anaemia, leading to acute and/or chronic tissue damage and organ dysfunction ${ }^{5}$. Sickle cell disease (SCD) is considered to be a hypercoagulable state with chronic activation of coagulation and an increased incidence of thrombotic events $^{6}$. The pathogenesis of coagulation activation in SCD appears to be multi-factorial, with contributions from ischemia-reperfusion injury and inflammation, hemolysis and nitric oxide deficiency, and increased sickle RBC phosphatidylserine expression, patients exhibit increased platelet activation, high plasma levels of markers of thrombin generation, depletion of natural anticoagulant proteins, abnormal activation of the fibrinolytic system, and increased tissue factor expression, even in the non-crisis "steady state ${ }^{7,8}$. The objective of current study was to compare the levels of (Protein C, S, D- dimer, PTT, PT, INR, TT and fibrinogen) in patients with sickle cell anemia in steady state and during vaso-occlusive crisis.

\section{Materials and methods}

This was a descriptive cross sectional study, which was conducted in the period from July 2015 to July 2017 in which a total of 72 participants previously diagnosed as SCD patients were included from both sexes' with a different ages. Among these samples 49 (68.1\%) were in steady state while the remained $23(31.9 \%)$ were in vaso-occlusive crisis. The study was approved by the ethi- cal review committee of the Sudanese ministry of health and faculty of graduate studies and scientific research. Informed consent was also obtained from the patients or their guardians.

Five milliltres of blood was collected aseptically with minimal stasis from each study participant $2.5 \mathrm{ml}$ into a tri-sodium citrate tube and $2.5 \mathrm{ml}$ was transferred into EDTA tube for coagulation profile tests and hemoglobin estimation respectively. Citrated samples were spurn at $3000 \mathrm{rpm}$ for 15 minutes then plasma was transported into plain tubes containers for fibrinogen, proteins $\mathrm{C}$ and S immediately analyzed or stored at -20 for less than 2 hours for patch investigations by using fully automated analyzer (Stago STA Compact Max®), however, Prothrombin time (PT), activated partial thromboplastin time (APT'T) and thrombin time (TT) were determined by using Stago STart4® Hemostasis Analyzer. While using NycoCard ${ }^{\mathrm{TM}}$ system for the D-dimer analysis.

Data was analyzed using SPSS Version 24. The one way ANOVA test was used. P value less than 0.05 was considered statistically significant.

\section{Results}

A total of 72 sickle cell anaemia patients were prospectively enrolled in this study. 40 (55.6\%) females and 32 (44.4\%) males. Twenty three (31.9\%) sickle cell anemia patients were in vaso-occlusive crisis, while 49(68.1\%) were in steady state with the absence of any clinically features of SCD in the previous 4 weeks (Table 1 ).

\section{Table 1 Means of hemoglobin concentration for all patients groups}

\begin{tabular}{|l|l|l|}
\hline Subject & Frequency & percentage \\
\hline Male & 32 & $44.4 \%$ \\
\hline Female & 40 & $55.6 \%$ \\
\hline Total & 72 & $100 \%$ \\
\hline Steady State & 49 & $68.1 \%$ \\
\hline Vaso -occlusive & 23 & $31.9 \%$ \\
\hline Total & 72 & $100 \%$ \\
\hline
\end{tabular}

Means of PT, INR, TT, protein c and s were within normal ranges for both genders while the means of APTT, D-dimer and fibrinogen were increased according to the normal range and the difference was significant in protein $\mathrm{S}$ between the male and female groups p. value $=0.017$ (Table 2). 
Table 2 Comparison of Coagulation profile in male and female patients

\begin{tabular}{|l|l|l|l|}
\hline $\begin{array}{l}\text { Parameter } \\
(\text { Normal range })\end{array}$ & $\begin{array}{l}\text { Male } \\
\text { Mean } \pm \text { SD }\end{array}$ & $\begin{array}{l}\text { Female } \\
\text { Mean } \pm \text { SD }\end{array}$ & $P$. value \\
\hline \begin{tabular}{l} 
PT $(11-16 \mathrm{sec})$ \\
\hline $\begin{array}{l}\text { INR } \\
(0.8-1.4)\end{array}$
\end{tabular} & $13.7 \pm 1.9$ & $13.8 \pm 1.7$ & 0.924 \\
\hline $\begin{array}{l}\text { APTT } \\
(25-40 \mathrm{sec})\end{array}$ & $42.7 \pm 8.4$ & $1.2 \pm 0.3$ & 0.805 \\
\hline $\begin{array}{l}\text { TT } \\
(14-21 \mathrm{sec})\end{array}$ & $15.8 \pm 1.3$ & $44.8 \pm 6.4$ & 0.260 \\
\hline $\begin{array}{l}\text { D-dimer } \\
(<0.3 \mathrm{mg} / \mathrm{l})\end{array}$ & $1.49 \pm 0.8$ & $16.1 \pm 1.5$ & 0.514 \\
\hline $\begin{array}{l}\text { Fibrinogen } \\
(2-4 \mathrm{~g} / \mathrm{l})\end{array}$ & $4.35 \pm 0.85$ & $1.53 \pm 1.2$ & 0.883 \\
\hline $\begin{array}{l}\text { Protein C } \\
(70-130 \%)\end{array}$ & $79.4 \pm 18.8$ & $70.6 \pm 20.8$ & 0.789 \\
\hline $\begin{array}{l}\text { Protein S } \\
(55-135 \%)\end{array}$ & $71.6 \pm 19.7$ & $59.0 \pm 14.9$ & 0.087 \\
\hline
\end{tabular}

$* \mathrm{P} \leq 0.05$ is significant

The comparison of means of coagulation profile for tients with (VOC) (P. value $=0.006$ ). PT, INR, APTT, steady state and patients with VOC group showed sta- TT, Fibrinogen level, Protein C and Protein S between tistical significance as increased D-dimer observed in pa- steady and VOC state were not clinically significant. (Table 3).

Table 3 Comparison between the patients with VOC and steady state

\begin{tabular}{|c|c|c|c|}
\hline $\begin{array}{l}\text { Parameter } \\
\text { (Reference } \\
\text { value) }\end{array}$ & $\begin{array}{l}\text { Steady State } \\
\text { Mean } \pm \text { SD }\end{array}$ & $\begin{array}{l}\text { Vaso-occlusive } \\
\text { Crisis } \\
\text { Mean } \pm \text { SD }\end{array}$ & $P$. value \\
\hline $\begin{array}{l}\text { PT } \\
(11-16 \mathrm{sec})\end{array}$ & $13.6 \pm 1.9$ & $14.1 \pm 1.7$ & 0.229 \\
\hline $\begin{array}{l}\mathrm{INR} \\
(0.8-1.4)\end{array}$ & $1.1 \pm 0.3$ & $1.1 \pm 0.1$ & 0.463 \\
\hline $\begin{array}{l}\text { APTT } \\
(25-40 \mathrm{sec})\end{array}$ & $43.7 \pm 6.7$ & $43.8 \pm 6.3$ & 0.764 \\
\hline $\begin{array}{l}\text { TT } \\
(14-21 \mathrm{sec})\end{array}$ & $15.8 \pm 1.3$ & $16.0 \pm 1.5$ & 0.208 \\
\hline $\begin{array}{l}\text { D-dimer } \\
(<0.3 \mathrm{mg} / \mathrm{l})\end{array}$ & $1.14 \pm 0.8$ & $2.02 \pm 1.5$ & $0.006^{*}$ \\
\hline $\begin{array}{l}\text { Fibrinogen } \\
(2-4 \mathrm{~g} / 1)\end{array}$ & $4.17 \pm 0.85$ & $4.54 \pm 0.76$ & 0.461 \\
\hline $\begin{array}{l}\text { Protein C } \\
(70-130 \%)\end{array}$ & $74.1 \pm 18.5$ & $71.6 \pm 16.3$ & 0.129 \\
\hline $\begin{array}{l}\text { Protein S } \\
(55-135 \%)\end{array}$ & $65.6 \pm 17.4 \%$ & $60.7 \pm 13.9 \%$ & 0.097 \\
\hline
\end{tabular}

$* * \mathrm{P} \leq 0.05$ is significant 


\section{Discussion}

The level of D-dimer was significantly higher in $71 \%$ of the patients; and significant elevation was observed in patients with VOC when compared with steady state, this are in keeping with many reports of elevated D-dimer in SCD ${ }^{9,10,11,12}$. Elevated plasma D-dimer levels indicate increased plasmin degradation of cross-linked fibrin, and are therefore an indirect indication of increased thrombin activity and fibrin formation. Increasing of thrombin activity and fibrin formation these increasing are features of steady-state sickle cell disease, and that they further increase during painful crisis ${ }^{13}$. With regard to protein $\mathrm{C}$ and protein S, patients with SCD our study reported decreased levels in most of the patients $(62 \%$ \& $81 \%)$ respectively with no significant differences according to patients' state (VOC \& Steady).This finding is in agreement with previous report among SCD patients ${ }^{14,15}$. Protein C and $S$ are natural inhibitors proteins and mechanism of lowered remains unknown but most authors explained the reduced levels of these natural anticoagulant proteins in SCD as a result of hepatic dysfunction that can decrease synthesis of protein $\mathrm{C}$ and $\mathrm{S}$, in addition consumptive coagulopathy ${ }^{15}$. However, no significant differences were encountered in the level of proteins $\mathrm{C}$ and $\mathrm{S}$ in the same patients during the steady state and during episodes of crisis similar to findings by El-Hazmi et al., concluded that the lower protein C and S levels in SCD is either due to decreased production or increased consumption though this reduction does not seem to play a role in producing thrombo- embolic disorders ${ }^{16}$. The fibrinogen concentration (FC) in our patients showed within high level has been observed in $67 \%$ of the patients and the difference between the VOC and steady state groups was statistically insignificant. This was in agreement to earlier studies which had reported elevated levels of fibrinogen in SCD patients in steady state, with a further elevation during crises ${ }^{17,18}$. Our finding also in contrast to study conducted by Mauryne et al, reported that the mean fibrinogen concentration (FC) in patients in steady state was within our normal reference range ${ }^{19}$. Our results showed normal APTT results in $54 \%$ of the cases and also no significant differences between the steady state and VOC groups, this finding agreed with prior studies of SCD patients ${ }^{16,17}$. The results of PT, INR and TT of all patients included in this study were withinthe normal range with no significant differences between the steady state and VOC groups. This finding was in contrast to several studies which had reported elevated levels of PT, INR and TT in SCD patients in steady state and during crises $^{18,19,20}$. Also our finding agreed with others studies conducted among $\mathrm{SCD}^{21,22}$. Most authors explain the prolongation of Prothrombin and thrombin time may be associated with lower levels of Factor V and VII, which may have been secondary to decreased hepatic synthesis or increased consumption from enhanced procoagulant activity ${ }^{23,24}$. There are several evidences that prove the multifactorial pathogenesis of hypercoagulability in SCD that include disturbing red blood cell phospholipids membrane asymmetry, abnormal activation of endothelial cells and other blood cells. The hypercoagulable state in SCD patients could be more complicated in the presence of inherited and acquired risk factors of thrombosis ${ }^{25}$.

\section{Limitations}

These include the relatively small sample size, and potential markers like those involved in neutrophil and platelets activation, thrombin generation test and quantitative measuring of coagulation factor especially factor $\mathrm{V}$ and VII which were not included due to shortage in materials and diagnostic procedures.

\section{Conclusion}

Elevated levels of D-dimer with further elevation during VOC indicating abnormal coagulation and fibrinolysis activation and patients during VOC require increased monitoring of coagulation activation markers testing as they undergo significant alterations that increase their risk of developing thrombophilia. Reduced levels of natural anticoagulants proteins $\mathrm{c}$ and s observed in our patients can be consider as further hepatic dysfunction with SCD, in addition consumptive coagulopathy.

\section{Acknowledgement}

This publication was supported by the Deanship of Scientific Research at Prince Sattam Bin Abdulaziz University. Special thanks to the Staff of hematology department, Faculty of Medical Laboratory Sciences, The national Ribat University.

\section{Conflict of interest}

There are no conflicts of interest.

\section{References}

1. Gomperts E, Belcher J, Otterbein L, Coates T, Wood J, 
Brett E, Howard Levy S, Vercellotti G. The role of carbon monoxide and heme oxygenase in the prevention of sickle cell disease vaso-occlusive crises. American Journal of Hematology. 2017; 92(6): 569-582.

2. Setty BY, Rao AK, Stuart MJ. Thrombophilia in sickle cell disease: the red cell connection. Blood. 2001; 98(12):3228-33.

3. Tewari S, Brousse V, Piel FB, Menzel S, Rees DC. Environmental determinants of severity in sickle cell disease. Haematologica. 2015;1;100(9):1108-16.

4. Akinbami A, Dosunmu A, Adediran A, Oshinaike O, Phillip A, Vincent O, et al. Steady state hemoglobin concentration and packed cell volume in homozygous sickle cell disease patients in Lagos, Nigeria. Caspian Journal of Internal Medicine. 2012;3(2): 405-409.

5. Quinn CT. Sickle cell disease in childhood. Pediatric Clinics. 2013 Dec 1;60(6):1363-81.

6. Naik RP, Streiff MB, Lanzkron S. Sickle cell disease and venous thromboembolism: what the anticoagulation expert needs to know. Journal of Thrombosis and Thrombolysis. 2013 Apr 1;35(3):352-8.

7. Noubouossie D, Key NS, Ataga KI. Coagulation abnormalities of sickle cell disease: Relationship with clinical outcomes and the effect of disease modifying therapies. Blood Reviews. 2016;30(4):245-56.

8. El-Hazmi MA, Al-Hazmi AM, Warsy AS. Sickle cell disease in Middle East Arab countries. The Indian Journal of Medical Research. 2011;134(5):597.

9. Ay C, Dunkler D, Pirker R, Thaler J, Quehenberger P, Wagner O, Zielinski C, Pabinger I. High D-dimer levels are associated with poor prognosis in cancer patients. Haematologica. 2012;97(8):1158-64.

10. Francis, Robert B. "Elevated fibrin D-dimer fragment in sickle cell anemia: evidence for activation of coagulation during the steady state as well as in painful crisis." Pathophysiology of Haemostasis and Thrombosis.1989; 19(2):105-111.

11. Dar J, Mughal I, Hassan H, Al Mekki TE, Chapunduka Z, Hassan IS. Raised D-dimer levels in acute sickle cell crisis and their correlation with chest X-ray abnormalities. GMS German Medical Science. 2010;8:1-4.

12. Idris MM, Rashad MO, Ghada MM. Assessment of hypercoagulability state among Sudanese sickle cell patients. Journal of Biomedical and Pharmaceutical. Research. 2015;4(1):95-99. 25.

13. Batesa D, Liub Z, Gibbonsa J, LeBedisb C, Holalk- ere N. Sickle cell disease and venous thromboembolism: A retrospective comparison of the rate of positive CT pulmonary angiography in the emergency department. European Journal of Radiology. 2019; 110: 256-259

14. Bayazit AK, Kilinc Y. Natural coagulation inhibitors (protein $\mathrm{C}$, protein $\mathrm{S}$, antithrombin) in patients with sickle cell anemia in a steady state. Pediatr Int 2001;43:592-6.

15. Saud WH, Hassan MK, Al-Salait SK. Coagulation activation in patients with sickle cell disease in Basra, Iraq. $J$ Appl Hematol:2017 ;8:54-60.

16. El Hazmi MAE, Warsy AS, Bahakim H. Blood protein C and S sickle cell disease. Acta Haematol. 1993;90:114117.

17. Famodu AA, Reid HL. Plasma fibrinogen levels in sickle cell disease. Tropical and Geographical Medicine. 1987 ;39(1):36-8.

18. Famodu AA. Coagulation changes in homozygous sickle cell disease in Nigeria. Journal of Clinical Pathology. $1987 ; 40(12): 1487$.

19. Ajuwon MD, Olayemi E, Benneh AA. Plasma levels of some coagulation parameters in Steady State HBSC disease patients. The Pan African Medical Journal. 2014;19. 20. Freedman ML, Karpatkin S. Elevated platelet count and megathrombocyte number in sickle cell anemia. Blood. 1975; 46: 579-582.

21. Nilesh T., Deepti J, Ingole NS, Nitin G. Haemostatic alterations in patients of sickle cell trait and homozygous sickle cell disease - A hospital based case control study. Indian Journal of Basic and Applied Medical Research. 2014; 3: 264-274.

22. Eissa AA. The clinical and haematological effects of hormonal contraception on women with sickle cell disease (Doctoral dissertation, UCL (University College London). 2014

23. Ahmed EM, Khalid IA, Mohammed KM, Mahmoud HS. A Study on the Changes in the First-line Coagulation Screening Tests in Sudanese Sickle Cell Disease Patients requirement for the degree of Bachelor with honours in Haematology and Immunohaematology July (Doctoral dissertation, university of khartoum).2011.

24. Nsiri B, Gritli N, Bayoudh F, Messaoud T, Fattoum S, Machghoul S. Abnormalities of coagulation and fibrinolysis in homozygous sickle cell disease. Hematology and cell Therapy. 1996 ;38(3):279-84.

25. Rahimi Z, Parsian A. Sickle cell disease and venous thromboembolism. MediterraneanJournal of Hematology and Infectious Diseases. 2011;3(1). 